\title{
Effect of rumen protected methionine and lysine on milk composition and on cheese yielding capacity
}

\author{
C Hurtaud, H Rulquin, R Vérité
}

INRA, Station de Recherches sur la Vache Laitière, 35590 Saint-Gilles, France

Postruminal infusions of lysine and methionine, the most limiting amino acids with maize silage diets, increase milk protein and casein contents (Le Hénaff et al, 1990, Reprod Nutr Dev, Suppl, 2, 237s ; Rulquin et al, 1990, Reprod Nutr Dev, Suppl, 2, 238s). The effect of rumen protected methionine and lysine (RPML) (Smartamine $M L^{T M}$ ) on milk composition and on coagulating properties for cheese making was compared to a negative control. It was examined on different diets in 4 Latin square experiments with 16 dairy cows/experiment (Rulquin et al, 1994a, J Dairy Sci, 77, Suppl, 1, 347 ; Rulquin et al, 1994b, Ann Zootech, 43, 245 ; Rulquin et al, 1994c, Ann Zootech, 43, 246). Protein concentrates varied either in nature (corn gluten meal or treated soya-colza meal or blood meal) to provide a wide range of absorbable lysine and methionine or in amounts to meet 100 or $120 \%$ of protein requirements. Experimental data were adjusted for "period", "nature or level of protein supplement" and "protein x RPML interaction" and analysed using the GLM procedure of SAS (SAS ${ }^{\circledR}$ User's Guide, Statistics, Version 6 Edition, 1987).

RPML significantly increased milk true protein and casein contents $(1.9$ and $1.6 \mathrm{~g} / \mathrm{kg}$

respectively). The casein/protein ratio did not change in contrast to results on duodenal infusions of methionine (Pisulewski et al, 1994, Ann Zootech, 43, 244). RPML had no effect on casein composition nor on colloidal calcium content but significantly decreased the colloidal calcium/casein ratio $(4.6 \%)$. This might be due to the secretion of the extra casein via a calcium-independent pathway (Knight et al, 1994, Liv Prod Sci, 39, 129-137). Laboratory cheese yield increased significantly (1.7\% units) in accordance with the increased casein content. Rennet coagulation time increased significantly $(1.7 \mathrm{~min})$ possibly due to the decrease in the colloidal calcium/casein ratio (Remeuf et al, 1991, Lait, 71, 397-421). RPML tended to decrease time of firming and to enhance firmness.

RPML had a positive effect on milk protein and casein contents and on most of technological properties. The latter would even have been improved to a greater extent if native colloidal calcium content of milk had been greater or if calcium $\left(\mathrm{CaCl}_{2}\right)$ had been added before measuring coagulating aptitude.

\section{RPML}

\section{Milk composition}

True protein content $(\mathrm{g} / \mathrm{kg})$

Casein content $(\mathrm{g} / \mathrm{kg})$

Casein/true protein (\%)

Colloidal calcium $(\mathrm{mg} / \mathrm{kg})$

Colloidal Ca/casein ( $p$ 1000)

Coagulating properties

Cheese yield (DM) (\%)

Rennet coagulation time (R) ${ }^{1}$ (min)

Time of firming $(\mathrm{K} 20)^{\dagger}$ (min)

Firmness (A30) ${ }^{1}$ (mm)

\section{Results from Formagraph analysis}

2 In one trial, control treatment included $15 \mathrm{~g}$ of methionine

310 to $15 \mathrm{~g} / \mathrm{d}$ of methionine and 24 to $34 \mathrm{~g} / \mathrm{d}$ of lysine

$\begin{array}{ccc}\begin{array}{c}\text { Methionine } \\ + \text { Lysine }^{3}\end{array} & \text { SE } & \text { RPML effect } \\ 33.9 & & \\ 27.6 & 1.21 & <0.001 \\ 81.5 & 1.13 & <0.001 \\ 919 & 0.70 & 0.153 \\ 33.3 & 58.86 & 0.507 \\ & 2.32 & 0.012 \\ 41.7 & 1.34 & <0.001 \\ 15.6 & 1.32 & 0.041 \\ 6.7 & 1.11 & 0.245 \\ 36.9 & 5.27 & 0.465\end{array}$

